Lise Esther Herman (2016)

\title{
Re-evaluating the post-communist success story Party elite loyalty, Citizen mobilization and the Erosion of Hungarian Democracy
}

European Political Science Review, Volume 8, Issue 2.

\begin{abstract}
:
In light of the instability of several Central Eastern European democracies following their accession to the European Union, most dramatically embodied by the 'constitutional revolution' taking place in Hungary since April 2010, this paper offers a critical reading of the dominant, rational-institutionalist model of democratic consolidation. Drawing on the Hungarian case, it argues that the conditions set out by this model are insufficient for ensuring a democratic regime against erosion. On this basis, the paper considers additional elements to understand Fidesz's reforms: the importance of deeper commitments to democracy among the leadership of mainstream parties, and the pivotal role of party strategies of citizen mobilization in the consolidation of young democracies. Drawing on these insights, the paper argues for approaching democratic consolidation as an agent-led process of cultural change, emphasising the socializing role of mainstream parties' strategies of mobilization in the emergence of a democratic political culture. The last section concludes with methodological and empirical considerations, outlining a three-fold agenda for future research.
\end{abstract}


Word count: 10598

Key words: Democratic consolidation; Central and Eastern Europe; Hungary; Political Parties

In 2007, Rupnik spoke of a "post-transitional and post-accession backlash against (the liberal) consensus" in Central Eastern Europe (CEE) (Rupnik, 2007, p. 20). Since then, democratic institutions have been weakened in several younger European Union (EU) member states - with direct challenges to judiciary, media, and administrative independence (Ágh, 2012; Freedom House, 2012). This has resulted in new entrants losing an average of 0.22 points on Freedom House's Nations in Transit democracy score between 2005 and 2014, and six out of ten of these countries to be downgraded in 2014 (Freedom House, 2014b). ${ }^{1}$

Before the 2004 enlargement, scholars of democratization studies were particularly optimistic as to the speed and quality of democratization in these countries (Clark, 2002; King, 2000, pp. 166-169; Schneider \& Schmitter, 2004). Along with CEE states like Slovenia, Poland and the Czech Republic, Hungary was considered a post-communist success story. The country achieved a peaceful and negotiated transition to democratic rule in October 1989, which was facilitated by one of the least stringent communist regimes in the region (Rothschild \& Wingfield, 2000, pp. 239-245). Subsequently, it developed viable parties that alternated regularly around two main party blocs until 2010, displaying one of the most

\footnotetext{
1 Freedom House's Nations in Transit democracy score is based on a seven point scale expert country ranking, according to the following criteria: transparency of electoral process, freedom of civil society, independence of the media, national and local democratic governance, judicial independence and corruption (Freedom House, 2014a)
} 
institutionalized party systems in the region (Casal Bértoa \& Mair, 2010; Lewis, 2006; Olson, 1998; Sikk, 2005). Hungary was among the first countries to open EU accession negotiations in 1998, and complied particularly successfully with membership requirements. These included the 'political' dimension of the Copenhagen criteria, which demanded from future member states that their institutions be governed by "the values of respect for human dignity, freedom, democracy, equality, the rule of law and respect for human rights" (Article 2 TEU) (Batory, 2008; European Commission, 2003).

However, this is also the country in the region that experienced the most severe erosion of its democratic institutions over the last decade, defying expectations of both academic analysts and EU public officials. The far-reaching constitutional reforms of conservative party Fidesz (Fiatal Demokraták Szövetsége) since the 2010 Hungarian Parliamentary elections, attracted criticism from a number of independent international organizations - including the European Parliament, the Council of Europe, the Norwegian Helsinki Committee, and the American State Department (Council of Europe, 2013; European Parliament, 2013; Norwegian Helsinki Commitee, 2013; United States Commission on Security and Cooperation in Europe, 2013): This paper takes as its point of departure the mismatch between positive assessments of the solidity of Hungarian democracy up to 2010, and the empirical reality of contemporary Hungarian politics since then. It explains this mismatch by the limits of the dominant analytical tools for understanding the role of mainstream political parties in post-communist democratization. On this basis, the paper aims to draw broader conclusions on how this role can be theorized and studied. 
Following the emergence of 'Third Wave' democracies (Huntington, 1991) - after a series of breakdowns of authoritarian regimes in Southern Europe, Latin American and the ex-Soviet bloc - a vast literature emerged that sought to monitor and explain the conditions and mechanisms according to which democratic regimes develop and survive. Scholars largely agree on how to define the first two phases of democratization: first, a period of liberalization, characterized by the non-democratic regime gradually conceding reforms; second, a period of democratic transition, considered as closed when a democratic constitution is agreed upon and the first competitive elections take place. The third phase of democratic consolidation - which is the focus of this paper - is a process by which the risks of erosion of the democratic institutions, established during the transition phase, are progressively reduced. It amounts to "transforming the set of democratic rules and institutions agreed upon in the transition phase into regular, acceptable and predictable patterns" (Kopecký \& Mudde, 2000, p. 520).

A great share of post-communist studies relied on rational-institutionalist models of democratic consolidation, established in the early 1990s, in order to understand the 'thirdwave' of democratization (O'Donnell, Schmitter, \& Whitehead, 1986; Przeworski, 1991; Schmitter, 1992; Schmitter \& Karl, 1991). To approach this body of theoretical work on its own grounds, this paper adopts Dahl's conception of democracy as 'polyarchy' - one of the procedural definitions most commonly used in this literature. ${ }^{2}$ Dahl defines polyarchy as a regime type in which "opportunities for public contestation are available to the great bulk of the population" (Dahl, 1971, p. 202). Both, opportunities for participation of all citizens

2 A number of scholars that set the 'canon' for the rational-institutionalist approach to democratization explicitly use Dahl's model (see for instance Huntington, 1991, pp. 7-8; O'Donnell, 1996, p. 35; Przeworski, 1991, p. 10; Schmitter \& Karl, 1991, p. 81) 
to the political process and their opportunities for contesting public decision-making, require institutional guarantees in eight different domains: 1 . Freedom to form and join organizations; 2. Freedom of expression; 3. Right to vote; 4. Eligibility for public office; 5. Right of political leaders to compete for support; 6. Alternative sources of information; 7. Free and fair elections; 8. Institutions for making government policies depend on votes and other expressions of preference (Dahl, 1971, p. 3). While the term polyarchy was coined to "maintain the distinction between democracy as an ideal system and the institutional arrangements that have come to be regarded as a kind of imperfect approximation of an ideal" (Dahl, 1971, p. 9), this paper will use the term democracy to designate a regime that fulfils the procedural criteria set out in Dahl's model of polyarchy.

Rational-institutionalist models define a consolidated democracy as one in which parties competing for power prefer to take part in an institutionalized form of political struggle, rather than challenge these institutional guarantees. In the words of Pzeworski, "democracy is consolidated when compliance - acting within the institutional framework - constitutes the equilibrium of the decentralized strategies of all the relevant forces" (Przeworski, 1991, p. 26). The relevant actors here are mainstream parties, understood not in terms of their ideological moderation but in terms of their capacity to form a single-party government or head a governmental coalition. According to rationalinstitutionalist frameworks, mainstream party compliance with the democratic process is dependent on the type of institutional framework established during the transition phase, its re-enforcement through subsequent steps of state-building, and the maintenance of a strong but balanced form of competition within this framework. 
After reviewing the rational-institutionalist model of democratic consolidation, the first part of this paper emphasises its limited explanatory power in the Hungarian case. Many scholars that were applying rational-institutionalist criteria considered Hungary one of the most 'consolidated' of CEE democracies. A strong Fidesz majority was, nevertheless, sufficient to undermine Hungarian democracy's 'procedural minimum', revealing a much weaker regime than that depicted by these studies. The second part offers a critical reading of the rational-institutionalist framework, and seeks to understand this lack of foresight. It emphasises that these theories both overestimated the protective power of well-designed institutions, and underestimated the role of party-citizen relations for the success of democratic consolidation processes. I then argue that successful democratic consolidation requires that a third condition be satisfied, namely, that the leadership of those parties that are successful in mobilizing mass popular support needs to have a deeper commitment to the democratic process. On this basis, the third part of the paper makes a case for revisiting cultural theories of democratic consolidation that insist on the central role of both mass and elite attitudes towards democracy. Building on these theories, it argues that the dynamics of party-citizen relations condition whether or not such commitments develop within society. Mainstream parties are agents of democratic cultural change as they contribute to the socialization of citizens in their strategies of mobilization. The last section concludes with methodological and empirical considerations, outlining a three-fold agenda for future research. 


\section{Theories of democratic consolidation and the Hungarian paradox}

\section{The rational-institutionalist approach}

The starting point for rational-institutionalist theories of democratic consolidation is the minimalist or procedural definition of democracy, first put forward by Schumpeter (Schumpeter, 1943). Dahl's concept of 'polyarchy' - a regime type that guarantees opportunities for all citizens to participate in the political process, and to contest public decision-making through a series of institutional arrangements - is a widely used standard in this literature (Dahl, 1971). The contention here is that more extensive definitions lead to conceptual confusion and measurement problems. Additional, non-procedural characteristics one could attach to a democratic ideal-type - high levels of education, a vibrant civil society, mass political engagement, a reasonable level of social equality, etc. are argued to matter only to the quality of democracy, rather than to the definition of democracy itself.

To satisfy the requirement of conceptual clarity, rational-institutionalist approaches also adopt a minimal definition of democratic consolidation, concerned solely with the integrity and survival of this 'procedural minimum' (Schedler, 1998, p. 103). These approaches focus on elite behaviour - rather than their attitudes - within this institutional framework. Democracy is considered consolidated when rational elites prefer to take part in an institutionalized form of political competition rather than attempt to subvert the system as a whole. Consolidation thus ultimately depends on whether the cost-benefit

analysis of key actors is favourable to democracy: if risks associated with non-compliance 
are greater than those associated with compliance, democracy will reach a self-enforced equilibrium (see Alevizakos, 2008; Clark, 2002; Przeworski, 1991).

Institutions are essential as they provide incentive structures that constrain selfserving actors - they reward compliant behaviour and sanction non-compliance. Parties first establish these institutions to jugulate the threats of unregulated competition. The initial constitutional design is thus seen to result from an 'elite pact' between the authoritarian regimes' hardliners, reformers, and a newly emerging counter-elite, as all have an interest in accepting free and fair elections rather than facing potential destruction (Di Palma, 1990; O'Donnell et al., 1986). Similarly, the subsequent phase of state building also results from the uncertainty created by elite competition. This is the case not only because the majority in place is less likely to abuse its own power if it is checked by a strong and vigilant opposition, but also because the weakening of state institutions is likely to play in its disfavour in the plausible event of electoral defeat (Grzymala-Busse, 2007). Grzymala-Busse's reliance on the image of Hobbes' Leviathan is a most adequate metaphor: as in the original social contract theory, elites accept the constraints of a given institutional framework because the alternative, an environment of intense competition, may imply their destruction by competing forces (Grzymala-Busse, 2007). This is the logic underlying Pzeworski definition of democracy as the 'institutionalization of uncertainty': competition among elites creates a climate of uncertainty, one that can only be eased through a framework that institutionalizes competition, and thus a democratic framework in the minimalist sense (Przeworski, 1991, ch. 1).

Well-designed democratic institutions, in turn, generate elite compliance by reducing the stakes of political battle. Proportional representation and parliamentarism 
are thus often viewed as 'low-stakes' institutional design, as they offer losers means to influence the policy process, and a real prospect of obtaining power in upcoming elections. Relevant actors can then calculate that the cost of future defeat within this institutional framework is preferable to the risks associated with regime overthrow (Przeworski, 1991, ch. 1). Democratic consolidation is then the process by which elites get locked into an institutionalized incentive structure favourable to democracy; an incentive structure that they themselves establish to jugulate the threats of unregulated competition.

\section{Empirical applications of the rational-institutionalist framework}

Classifications of the speed and quality of democratization in the post-communist world systematically placed CEE countries at the forefront, and even the most sceptical authors considered them exceptional examples of democratic success (for instance Carothers, 2002, p. 9; Tismaneanu, 2002, p. 5). Many of these positive assessments implicitly or explicitly relied on the premises of rational-institutionalism. The strong focus of post-communist studies on the constitutional frameworks that resulted from the transition period in CEE countries - including the system of checks-and-balances and the type of electoral system - typically stemmed from the assumption that these frameworks could provide incentives for actors to respect the democratic rules of the game (Zielonka, 2001). The scholarly debate as to the respective merits of parliamentarism and presidentialism for the survival of democracy is most emblematic in this regard (Lijphart, 1992; Linz \& Valenzuela, 1994). In the second, post-transitional phase, scholars focused on the extent to which institutions protect state resources - in terms of both financial assets and employment opportunities - against elite exploitation. They took specific interest in the 
institutional guarantees for the transparency, openness, and fairness of state assets in CEE (Brada, 1996; Stark \& Bruszt, 1998). The independent functioning of the judiciary, as well as strong institutions of oversight supervising respect for electoral procedures and fundamental liberties, were prime objects of study (Grzymala-Busse, 2007). Institutions were also central for the assessments of democratic progress made by international organizations. For instance, the opening of EU accession negotiations for most of these countries in the late 1990s was conditioned upon an acceptance of the Copenhagen criteria. Established in 1993, these are based not only on candidates respecting the acquis communautaire, but also on the institutional framework of democracy. This 'political' dimension of the Copenhagen criteria thus required CEE countries to set up an effective process of judicial review, to address the issue of clientelism and corruption, and to guarantee both political and civil freedoms, especially for minorities (Grabbe, 2006).

The focus of post-communist studies on parties and party systems also results from the prevalence of rational-institutionalist understandings of democratic consolidation. Both, the development of parties as organizations of the state, and the increased regularity of patterns of party competition were taken as indicators of the compliance of mainstream actors to the rules of the democratic game. Scholarly attention was, for instance, directed towards the ability of parties to develop as organizations and fulfil their functions as actors within the state, for instance to organize Parliament, formulate goals and policies, maintain a stable share of the vote, professionalize, build administrative capacity, and find sources of financing (see for example Enyedi, 2006; Kopecký, 2007; Krasovec, 2001; Szczerbiak, 2001; van Biezen, 2003). Party system institutionalization - the increased regularity of patterns of competition, ideally structuring over time around two main party blocs - was also taken as 
a sign of democratic consolidation. In line with the rational-institutionalist framework, "the mark of a genuinely consolidated democracy (...) is the degree to which the alternation of parties in power is regular and accepted" (Lewis, 2001a, p. 203). This logic is exemplified by Huntington's 'two-turnover test', according to which a democratic regime can be considered consolidated when it undergoes two peaceful turnovers of ruling parties in transparent and fair elections (Huntington, 1991, p. 267). ${ }^{3}$ The fact that elections repeatedly provoke power alternation without the results being challenged, thus offer a strong indication that the institutional set-up is providing the right incentives to salient actors. Such a concern also explains the wealth of studies that focused on the number of parties competing in each successive election, their size, the degree of polarization within the party system, the degree of electoral volatility, and patterns of alliances between parties (see for example Birch, 2001; Lewis, 2001a, 2001b, 2006; Markowski, 2001b; Olson, 1998; Sikk, 2005; Toole, 2000).

The empirical studies of the early 2000s supported the hypothesis that parties and party systems were effectively institutionalizing - and thus democracy consolidating - in most CEE countries, with Hungary, the Czech Republic, Estonia, and Slovenia as frontrunners. With the exception of Vladimir Mečiar's Movement for a Democratic Slovakia (HZDS), mainstream CEE parties preferred to follow, rather than subvert, the rules of the

\footnotetext{
3 In Huntington's words, "( $\mathrm{t}$ )he party or group that takes power in the initial election at the time of transition loses a subsequent election and turns over power to those election winners, and if those election winners then peacefully turn over power to the winners of a later election" (Huntington, 1991, p. 267).
} 
democratic game. ${ }^{4}$ By the mid-2000s all of the future EU members had fulfilled Huntington's two-turnover test, and most displayed party systems with increasingly regular patterns of competition. The willingness of ex-communist parties to reform was considered an essential sign of the consolidation of CEE democracies (Bozóki \& Ishiyama, 2002; Grzymala-Busse, 2002; Hanley, Szczerbiak, Haughton, \& Fowler, 2008; Ishiyama, 1999). While radical parties did achieve representation in the 1990s, they were excluded from governmental coalitions and lacked the broad support to be a serious democratic threat (Lewis, 2001a, p. 203; Millard, 2004, pp. 119-127).

The Hungarian case, especially. was considered a model of democratic consolidation until 2010. The country experienced one of the smoothest transitions to democracy in the region, with the development of a range of viable opposition parties as early as 1988, and the radical revision of the constitution in October 1989 (Hungarian Parliament, 1989). While the latter did not meet all the features of a 'low-stakes' design, because of a mixed electoral system and a fairly flexible procedure for constitutional amendment, it was nevertheless considered to "satisfy the needs for democracy" (Szikinger, 2001, p. 429). The Hungarian Communist party held its last congress during this same month, and converted to a social-democratic platform under the MSzP (Magyar Szocialista Párt) party banner. The first democratic elections followed in May 1990, during which the centre-right MDF scored 43\% of votes (Rothschild \& Wingfield, 2000, pp. 239-245). By the late 1990s, Hungary displayed what many scholars classified as the most institutionalized party

\footnotetext{
4 The party led a governmental coalition twice in the periods 1992-4 and 1994-8 with Vladimir Mečiar as Prime Minister. Controversial decisions included disrespect for media independence, a privatisation process that lacked transparency, and a discriminatory policy towards national - especially Hungarian - minorities. This prompted the EU to exclude Slovakia from the group of six countries that started accession negotiations on 31 March 1998, and delay these negotiations by two years (Hungary, Poland, Estonia, the Czech Republic, Slovenia and Cyprus) (for a detailed analysis of the Mečiar years, see Cohen, 1999).
} 
system in CEE: strong elite competition, regular alternation between two main parties, and a rather robust institutional framework as compared to many other CEE countries (Casal Bértoa \& Mair, 2010; Grzymala-Busse, 2007; Lewis, 2006; Sikk, 2005). Further, Hungary was among the first post-communist countries to meet the Copenhagen criteria, and to start EU accession negotiations in 1998 - these went particularly smoothly, as compared to other countries such as Poland for instance (Batory, 2008).

\section{Challenges to democracy's 'procedural minimum' in Hungary}

Despite these positive assessments, democracy's 'procedural minimum' has been undermined in several CEE countries following their accession to the EU. In Poland, the conservative Law and Justice party (PiS) initiated several controversial institutional reforms in 2005-2007 that challenged the independence of the Polish administration (Jasiewicz, 2007, pp. 30-32; Michnik, 2007; O'Dwyer, 2008, pp. 1184-1187). Citizens for the European Development of Bulgaria (Gerb), the conservative party that won the Bulgarian parliamentary elections in 2009 and 2013, was accused of electoral fraud in the parliamentary elections of May 2013 (Troev \& Buckley, 2013). Similarly in 2012, Viktor Ponta's leftist Social Liberal Union (SUL) interfered in the proceedings of the country's Constitutional Court to suspend Romania's president Traian Basescu, shortly after having won an absolute majority in the parliamentary elections (Buckley, 2012).

The case of Hungary remains the most puzzling. While it was set as a model of democratic consolidation in the EU's post-communist space, it also experienced the most severe challenges to democratic institutions that were taking place in the region since the end of communism (Council of Europe, 2013; Dani, 2013; European Parliament, 2013; Kornai, 2011; Norwegian Helsinki Commitee, 2013; United States Commission on Security 
and Cooperation in Europe, 2013). In the Spring of 2010, the Fidesz-KDNP coalition obtained $52.7 \%$ of the votes, a score that translated into a two-third majority in Parliament given Hungary's mixed electoral system (Benoit, 1996). ${ }^{5}$ Reaching such a threshold allowed Fidesz to initiate a process of constitutional re-drafting: 18 April 2011 it adopted a new Fundamental Law, and amended it five times since (Hungarian Parliament, 2011; Kovács \& Tóth, 2011). Subsequently, an extensive series of Cardinal Acts were passed, including acts on the Protection of Families, on Religion and Church-State Relations, on Media Freedom, on the Rights of Nationalities, on the Judiciary, on the Constitutional Court, as well as a new Election Law (Bánkuti et al., 2012). ${ }^{6}$

It is beyond the scope of this article to offer an exhaustive analysis of these reforms the reader is referred to the official reports and scholarly articles cited above for such analyses. Instead the following sections provide a limited number of examples, intending to demonstrate that the 'procedural minimum' of democracy - as defined in Dahl's conception of polyarchy - was eroded by these reforms. This is the case for six of the eight domains in which institutional opportunities should exist for the participation in, and the contestation of, public decision-making in Dahl's model (Dahl, 1971, p. 3):

\section{Freedom to form and join organizations}

New Cardinal Acts were enacted on the freedom of association and regulation of NGOs in 2011, namely Act CLXXV/2011 on the Freedom of Association, Public Benefit Status and

\footnotetext{
5 Turnout was of $64 \%$ at the first round; $46 \%$ at the second. The Fidesz/KDNP party list obtained $52.7 \%$ of the vote, 263 seats and $68.1 \%$ of Parliament; MSzP (Socialists), 19.3\% of the vote, 59 seats and 15.3\% of Parliament; Jobbik (Far right), $16.6 \%$ of the vote, 47 seats and $12.2 \%$ of Parliament; LMP (Green), 7. 7\% of the vote, 16 seats and $4.1 \%$ of Parliament (Hungarian National Election Office, 2010)

6 These require a two-third parliamentary majority for both adoption and amendment
} 
the Operation and Support of CSOs and Act CLXXXI/2011 on the Court Registration of CSOs and the Relative Procedural Rules. Since then, Fidesz is suspected of distributing government funds according to partisan criteria. The number of organizations receiving the funds was divided by three - in a country where in $2012,40 \%$ of non-governmental organizations' (NGO) revenues originated from the state (Hungarian Central Statistical Office, 2013). Further, civil society organizations such as the Joint Civil Forum (Civil Összefogás Fórum - CÖF) were particularly favoured by the National Cooperation Fund (NEA), in charge of distributing these funds. In past years, the CÖF organized a number of pro-government rallies under the name of Békemenet (Peace March), and the head of the CÖF, László Csizmadia, is also the NEA council's current chair.

Fidesz also exerted pressure on associations not supported by the government. On June 19, 2014, the Government Control Office (KEHI) gave thirteen NGOs, financed by the Norwegian Civil Support Fund, a week to release all information concerning their financing7. On September 8, 2014, Hungarian police raided the Ökotárs foundation that was in charge of disbursing these funds. Targeted organizations, such as Transparency International, view these actions as politically motivated, and destined to intimidate independent civil society organizations (Transparency International Hungary, 2014). The existence of a legal basis for the audit of these organization was also questioned in an opinion issued on July 23, 2014 by Hungarian Ombudsman László Székely (Székely, 2014).

\section{Freedom of expression}

\footnotetext{
7 The complete list includes Társaság a Szabadságjogokért (TASZ), Nők a Nőkért Együtt az Erőszak Ellen Egyesület (Nane), Magyar Női Érdekérvényesítő Alapítvány, Patriarchátust Ellenzők Társasága (Patent), Transparency International Magyarország Alapítvány, K-Monitor Közhasznú Egyesület, the Asimov Alapítvány, Labrisz Leszbikus Egyesület, Szivárvány Misszió Alapítvány, Liberális Fiatalok Egyesülete, Demokratikus Ifjúságért Alapitvány and Roma Sajtóközpont.
} 
Two Cardinal Acts that established a new Hungarian Media Authority in 2010 figured among the most controversial of Fidesz reforms. ${ }^{8}$ They establish appointment procedures that compromise this authority's independence from government, and provide it with over-extensive powers to regulate private and public media content. 'Balanced reporting' is now required for television and radio broadcast, and this provision is linked with a complaint system open to all citizens. ${ }^{9}$ If the Media Council determines that media outlets violate this requirement, it can impose a fine, demand that the Council's decision be published or broadcasted, as well as for the petitioner to be provided with an opportunity to publish his viewpoint.

As stated by the OSCE critical report on Hungary's media situation, "a legal obligation on what content media outlets should have is not in line with free media and freedom of expression" (OSCE, 2011). There exist concerns especially that these provisions will result in the self-censorship of media outlets (for a summary of these reforms, see Council of Europe Commissioner for Human Rights, 2011; OSCE, 2011, pp. 10-13; Political Capital, 2011).

\section{Right to vote and 4. Eligibility for public office}

The Elections Act and Election Procedure Act restrict the eligibility and the voting rights of persons with mental disabilities, prisoners and ex-prisoners. ${ }^{10}$ This resulted in the total disenfranchisement of 95,000 persons in the 2014 elections, including 26,000 individuals guilty of criminal offences that had already completed their prison sentence.

8 The new Media Constitution was passed in two steps: a Media Structure Act on July 22, 2010 (Act LXXXII of 2010 on the Modification of Certain Acts Regulating the Media and Electronic Communications), which established the National Media and Communications Authority (NMCA) and its Media Council; and a second package on December 21, 2010, which created regulations for media content and for the internet (Act CLXXXV of 2010 on Media Services and Mass Media).

${ }^{9}$ Article 10 of Act CIV and Article 12 (1) and (2) of Act CLXXXV and Article 181 of Act CLXXXV.

10 See CCIII/2011 Voting Rights Act, XXXVI/2013 Electoral Procedure Act. 
These provisions were considered to 'lack proportionality' by the OSCE's Office for

Democratic Institutions and Human Rights, and to contravene paragraphs 7.3 and 24 of 1990 OSCE Copenhagen Document and International Covenant on Civil and Political Rights $(\mathrm{ICCPR})^{11}$

\section{Right of political leaders to compete for support}

While legislation issued by the Fidesz government did not directly affect the right of leaders to compete for support, Article $U$ of the Fundamental Law opens the door to such interference. This article stipulates that organizations related to the ex-Hungarian communist party are 'criminal', and mentions explicitly that the successor to this party, the MSzP, shares responsibility in these crimes. While this does not directly restrict the rights of the Hungarian Socialist Party to compete for support, the wording of this article is sufficiently vague that it could serve as a legal basis to do so. ${ }^{12}$

\section{Alternative sources of information}

Concerns exist over the restriction of media pluralism in Hungary. The government recently introduced fiscal arrangements that overwhelmingly burden the last major independent television channel in the country, the German-owned broadcaster RTL Klub. A $40 \%$ tax on media advertising revenues exceeding HUF 20 billion was adopted on April 11, 2014, while revenue below HUF 500 million is exempt from tax. Other factors curtail alternative sources of information in Hungary, such as the shrinking private advertising

\footnotetext{
${ }_{11}$ There are also concerns surrounding equal access to voting for out-of-country voters (see OSCE, 2014, pp. 5-6, 10). The registration and voting process for citizens living abroad with permanent residence in Hungary is more stringent than for citizens living abroad with non-permanent residence in Hungary (see OSCE, 2014, pp. 5-6, 10).

12 Article $U$ of the Hungarian Fundamental law: "( $\mathrm{t}$ )he Hungarian Socialist Workers' Party and its legal predecessors and the other political organisations established to serve them in the spirit of communist ideology were criminal organisations, and their leaders shall have responsibility without statute of limitations (...) (p)olitical organisations having gained legal recognition during the democratic transition as legal successors of the Hungarian Socialist Workers' Party continue to share the responsibility of their predecessors as beneficiaries of their unlawfully accumulated assets".
} 
market, the growth of private investments by business actors supportive of Fidesz over recent years, and the pro-government bias of the public media sector (see Freedom House, 2014c).

\section{Free and fair elections}

Between 2010 and 2013, three new Cardinal laws regulating Parliamentary elections were enacted. ${ }^{13}$ A number of their provisions make the electoral system more majoritarian, and thus increase the advantage given to the leading party in an election. ${ }^{14}$ Further, these acts include a number of provisions that favour Fidesz more specifically. For instance, the new constituency map is designed to compensate a slight left-wing lead; campaign advertising regulations advantage the government party; and acquiring electoral suffrage was facilitated for non-resident Hungarians in neighbouring countries, a population among which Fidesz voters are over-represented (for a summary of these changes and their consequences, see Bozóki, 2013; Political Capital, 2013).

As demonstrated here, the reforms initiated by Fidesz eroded institutional guarantees for Hungarian citizens' participation in, and contestation of public decisionmaking in a majority of the eight domains stipulated by Dahl's 'procedural minimum'. While the history of consolidated democracies offers many examples of institutional reforms destined to favour the party in power (Alexander, 2001; Renwick, 2010) practices of gerrymandering being a case in point - these remain limited compared to the

13 See CCIII/2011 Voting Rights Act, XXXVI/2013 Electoral Procedure Act and LXXXVII/2013 Campaign Finance Act.

14 Such provisions include a decrease in the number of parliamentary mandates distributed on party lists in favour of those distributed in individual districts; a first-past-the-post system established for individual district mandates; and the lowering of requirements for establishing new parties and fielding candidates. 
scope of contemporary developments in Hungary. Given that, as shown earlier, most accounts relying on the rational-institutionalist framework classified Hungarian democracy as 'consolidated' before 2010, it appears necessary to engage a critical reading of these theories. The following section examines two additional factors that affect democratic consolidation: the deeper commitment of party elites to the democratic process, and the capacity of parties to mobilize citizens.

\section{Identifying additional factors: party loyalty and citizen mobilization}

\section{Elite loyalty or the insufficiency of institutional guarantees}

In the rational-institutionalist framework, well-designed institutions and sustained competition ensure that for all relevant actors the costs of undermining democratic institutions are greater than the risks of facing future defeat. The events that followed the 2010 elections in Hungary can thus be read as a reverse case, in which non-compliance became a rational course of action for Fidesz. In other words, as the elections results and the institutional design of the Hungarian state offered Fidesz the opportunity to undermine democracy's 'procedural minimum' at very little cost, it seized this opportunity. This begs the question, however, whether any democratic regime could persist over time if party elites were to systematically adopt such a reasoning in comparable circumstances, i.e. when faced with a strong electoral outcome and relatively weak institutional constraints. Further, it raises the possibility that other, non-procedural conditions - and namely, deeper commitments of elites to the democratic process - are necessary to the long-term survival of democracy. 
Alexander makes this argument explicit by applying theories of democratic consolidation to 'first wave democracies' - which a rational-institutionalist understanding would undeniably classify as 'consolidated' (Alexander, 2001, 2002a, 2002b). First, established democracies count a number of 'high-stakes' frameworks, that increase the costs associated with electoral defeat and set weaker limitations on the power of winning majorities. These include institutional designs that favour, for instance, unitary rule over devolution, or majoritarian electoral systems over proportional representation (Alexander, 2001, p. 265). ${ }^{15}$ The exceptionally high scores achieved by Fidesz in 2010 would thus have converted into a comparably high number of seats in many established democracies notwithstanding the fact that Hungary's previous mixed electoral system did not display all the features of a 'low-stakes' design (see Benoit, 1996; Szikinger, 2001). Democracies with high-stakes frameworks, such as France or Britain, nevertheless survived over decades. This encourages one to consider additional characteristics of these systems, appart from institutional design, that make them more resistant than the Hungarian framework.

Institutions are also far more malleable than posited by the rational-institutional framework, constitutions necessarily including amendment or re-drafting provisions. While requirements vary from one country to another, the parliamentary route - as opposed to revision through referendum - generally involves some form of a qualified parliamentary majority. In Hungary for instance, the threshold for a new constitutional

15 Alexander offers a number of examples: "systematic win- and loss-dispersing designs have not been the norm among well-established democracies". The quintessential stable democracy, Britain, exemplifies Lijphart's power-concentrating design (Lijphart, 1984). A number of West European countries famously wed parliamentarism and PR, but this generally coexisted historically with high-stakes features, such as unitary rules, rather than federalism; prominent trends toward devolution in Belgium, France, Spain, and Britain occurred only once democracies were already generally acknowledged to be consolidated. Judicial oversight has also often been relatively weak in the region. In turn, federalism has been more prominent among consolidated democracies with high-stakes plurality electoral rules: Australia, Canada, and the US. This does not imply that low political risks are irrelevant to democratic stabilization. But a low-stakes institutional design appears to be neither a sufficient nor necessary condition for perceptions of low risk in democracy"(Alexander, 2001, p. 265). 
drafting was raised in 1995 from a two-third parliamentary majority to a four-fifths one. ${ }^{16}$ Clearly however, while high thresholds for constitutional revisions "might be expected to have the best chance of not generating endogenous revision impulses", they cannot ensure that institutions will be "self-perpetuating or vulnerable only to exogenous shocks" (Alexander, 2001, p. 261). In the last half-century, the history of European democracies is permeated with examples of constitutional revisions. While much of these were designed to favour the party initiating them, they did not fundamentally and durably challenge the 'procedural minimum' of these democratic regimes (Alexander, 2001, pp. 263-264; Renwick, 2010). Undermining the institutional framework of democracy can, therefore, take more incremental forms than posited in the rational-institutionalist model. In other words, the choice opened to actors is not between a violent coup d'état and blind compliance to the democratic process - there is instead a wealth of intermediary possibilities, ranging from the practice of gerrymandering frequent in many established democracies, to the more radical constitutional transformations enacted by Fidesz.

To sum-up, many existing democratic frameworks allow for the emergence of strong majorities, and for these majorities to challenge the 'procedural minimum' of democracy through constitutional change at relatively low cost. If historically in these situations some actors, nevertheless, preferred institutionalized competition to radical constitutional reforms, this also means that additional factors to the institutional design encouraged these actors towards compliance. This implies that while well-designed institutions and high political competition may set favorable conditions to democratic consolidation - by increasing the benefits of playing according to the rules and heightening the risks

16 The two-third threshold for amendments was left untouched. One of Fidesz's first decisions was to amend the previous constitution, and lower the threshold for constitutional re-drafting. 
associated with challenging the system - they are, nevertheless, insufficient to guarantee a democratic regime against erosion. Additional conditions to those set out by the rationalinstitutionalist model thus require to be identified, conditions under which the 'procedural minimum' of a new democracy may be considered protected.

One hypothesis would be to set the deeper attachment of mainstream elites to the democratic process, or elite loyalty, as such a condition. Actors that are solely driven by the desire to acquire more power are likely to seize any available opportunity to do so. That institutions are cemented and perpetuated by the ideas and beliefs of those who act within them is an insight long recognised by cultural approaches to institutions (Bevir \& Rhodes, 2010; Gofas \& Hay, 2007; Schmidt, 2008). Deeply-ingrained democratic norms are thus likely to play a key role in the fact that mainstream elites in high-stakes systems, such as France or Britain, do not subvert democracy when their party obtains a strong parliamentary majority.

The question of elite loyalty to the democratic process has been given only limited empirical attention. As previously underlined, many post-communist scholars implicitly assumed that mainstream parties in CEE countries were prepared to comply with the democratic process, based on their respectful behaviour in the decade following the initial phase of transition. Problematic actors are generally identified based on pre-conceived assumptions, rather than empirical examination. Thus, many CEE democracies were declared consolidated on the premises, first, that extremist parties achieved a rather limited electoral success and were marginalized by mainstream forces; second, that reformed communist parties had accepted the democratic agenda. On the other hand, as Hanley repeatedly insisted, mainstream governmental parties from the conservative right - 
those that are today most problematic in both Hungary and Poland - received the least attention in the 1990s compared to those other two groups of parties, and they were also subject to the least political and academic concern (Hanley et al., 2008, pp. 407-408; Szczerbiak \& Hanley, 2004, p. 1). Fidesz was not a newcomer in Hungary: between 19982002 it led a first governmental coalition with its Christian-democratic ally, the KDNP, and lost the 2002 and 2006 elections only by a short margin to its main opposition party, the MSzP (OSCE, 2002; Sitter \& Batory, 2006). Few scholars would have then considered this party as a threat to the democratic process. The lack of attention to elite commitments to democracy in CEE, thus leads to the situation where scholarship did not identify as problematic a mainstream government party that subsequently challenged the democratic process.

\section{The overlooked role of party-citizen dynamics}

While rational-institutionalist approaches over-estimated the protective role of well-designed institutions, they also under-estimated the function party-citizen dynamics may play in the success or failure of democratic consolidation. Two main assumptions structure scholarly approaches to party-citizen relations in CEE. First, in a context of widespread political disengagement, citizen mobilization by parties - their capacity to gain popular support - was seen in a positive light since the mid-1990s. Second, while important for the quality of newly-found democracies, the development of party-citizen links was not considered essential to the continued integrity of democratic institutions, and thus for democratic consolidation per se. In the case of Hungary, however, the mobilization of citizens by a mainstream party was not only problematic for the democratic process, but a determinant factor in the erosion of democracy's 'institutional core'. The following 
considers these points in turn.

A large number of survey-based and electoral studies took party-citizen links in CEE as their subject of enquiry. Much of this scholarship expects the development of these links to positively affect the quality of newly-formed democracies over time. One category of literature focuses on correspondences between cleavages within society and political divisions within party systems. These studies identified correlations of various sociodemographic characteristics with party preferences, correlations of socio-demographic characteristics with value patterns and policy preferences, and correlation of value patterns and policy preferences with party preferences (Evans \& Whitefield, 1998, 2000; Miller \& White, 1998; Rose \& Makkai, 1995; Tóka, 1996, 1998; Tworzecki, 2003; van der Brug, Franklin, \& Tóka, 2008). A second category of studies focuses on levels of political engagement in CEE. Despite the development of political cleavages, this engagement remains significantly below that of Western European citizenries. Such trends include lower and often declining voting turnouts (Millard, 2004, pp. 73-81), lower levels of party membership (Mair, 1997, pp. 185-186), higher levels of electoral volatility (Mair, 1997, pp. 187-192; Sikk, 2005), lower levels of trust in representative institutions (Dimitrova-Grajzl \& Simon, 2010; Mishler \& Rose, 1997, pp. 427-429; Misztal, 1996, p. 192), and lower levels of party identification (Rose \& Mishler, 1998, pp. 221-223).

The CEE party studies share this positive outlook on the development of partisan ties within society. Nevertheless, they do not describe the mobilization of citizens by parties as a determinant factor in the continued integrity of democratic institutions. The weakness of partisan ties in CEE is generally considered a regrettable, yet transitory phenomenon; a problem that can be expected to regress over time, rather than a reservoir 
on which populist mobilization may subsequently thrive. An implicit assumption of this literature is that party system institutionalization will further citizens' ability to identify with parties. Markowski lists the following positive consequences of increasingly regular patterns of competition: '"clarity of responsibility", "decisiveness of elections", "political representation", (real) "opportunity for political choice" (system alternativeness) and other features of contemporary democracies (i.e. effectiveness, efficacy, political support, etc)' (Markowski, 2001a, p. 48).

The importance of party-citizen ties in CEE was also minimized by invoking the high levels of citizen disengagement in older democracies (on the situation of established democracies, see Dalton \& Wattenberg, 2000; Hay, 2007; Pharr \& Putnam, 2000). If consolidated democracies have already gone beyond the stage of mass mobilization, then no greater engagement can be expected in newer democracies; nor is such engagement a crucial factor of democratic survival. For instance, Schmitter argues that any expectation of strong citizen mobilization in Eastern Europe "ignores the very substantial changes that took place in the nature and role of parties in well-established Western democracies" (Schmitter, 1992, pp. 426-427). Similarly, Kitschelt et al. put that "the absence of mass party membership in Eastern Europe (...) may simply be a result of the fact that these democracies have come into existence in an era of 'post-modern' politics" (Kitschelt, Markowski, Mansfeldova, \& Toka, 1999, p. 395; for similar stances, see Ishiyama, 2001, p. 35; Lewis, 2001, pp. 204-207).

The 'economic losers' of the early 1990s were often depicted as destabilizing forces, with the potential of being mobilized against drastic economic reforms and the democratic process itself (Przeworski, 1991; Vanhuysse, 2006). By the early 2000s, however, few 
studies took such a scenario seriously. Fidesz's strategies of citizen mobilization however played a crucial role in the subsequent erosion of democratic institutions in Hungary. The party could not have carried out its constitutional reforms without the strong majority it obtained in April 2010. The Fidesz-KDNP joint list then rallied 52.36\% of expressed votes, a gain of over 10 points as compared to the previous 2006 parliamentary elections. Its main opponent, the MSzP, achieved a mere $19.3 \%$ of the votes in 2010, losing 24 points as compared to four years before. As will be discussed in the last section of this paper, this was also made possible because of Fidesz's strategies of mobilization: a strong populist message, and the development of one of the most socially embedded party organizations in post-communist Europe (Enyedi, forthcoming; Enyedi \& Linek, 2008). These developments contradict the assumptions made by the literature on the relationship between citizen mobilization by political parties and processes of democratic change. As stated above, this type of engagement has mostly been pictured as a factor that contributes positively to the quality of an emergent democracy, but is not pivotal to its institutional survival. In contrast, Fidesz's strong form of mobilization set the conditions for the constitutional core of Hungarian democracy to be undermined. Indeed, the electoral outcome of this mobilization provided the party with both the political legitimacy and the institutional power to carry out its reforms after 2012 .

A second condition for democratic consolidation can therefore be formulated: party elites that do not hold deep commitments to the democratic process may exist within the party system of a consolidated democracy, but only on the condition that they fail to mobilize mainstream popular support. The French Front National or the British National Party would be more likely to favour reforms of the type initiated in Hungary, but they are 
not able to mobilize the critical number of citizens to implement such reforms. This calls for an investigation of the conditions under which 'disloyal' parties are successful at mobilizing citizens and more generally, what makes for a good strategy of mobilization. In this regard, only a minority of studies have gone beyond the analysis of patterns of party interaction to take an interest in the substance of party competition and the content of parties' claims to represent citizens (for exceptions, see Grzymalala-Busse \& Innes, 2003; Innes, 2002; Roberts, 2010). There is also little work concerning what Katz and Mair termed the 'party on the ground' (Katz \& Mair, 1995) - parties' organized membership. More generally, the actual practices of citizen mobilization by parties - for instance through the organization of protests and rallies, or the development of ties with civil society organizations - have been understudied (Enyedi \& Linek, 2008).

From here, additional conditions to the ones set out by the rational institutionalist model can be identified, under which the 'procedural minimum' of a new democracy may be considered as protected from the threat of erosion. These may be spelt out in the following proposition: a democracy is consolidated when no mainstream political party displays a lack of commitment to the democratic process and has a strong capacity for citizen mobilization. The second half of this paper builds on the above-analysis to suggest some avenues of theoretical and empirical research. More specifically, it defends the need to theorize and study democratic consolidation as a process of cultural change in which party-citizen interactions play a central role. The following section describes existing culturalist approaches to democratization, and the reasons why these have been less influential than their rational-institutionalist counterparts. It then underlines ways in 
which party strategies of citizen mobilization can be integrated within a cultural approach to democratic consolidation. On this basis, the fourth section of the paper outlines an agenda for future empirical research.

\section{The agency of parties in democratic forms of cultural change}

\section{Culturalist approaches and their critics}

A number of authors emphasise the importance of mass and elite attitudinal transformations for the long-term survival of democratic regimes. In this understanding, that can be referred to as 'culturalist', democracy is consolidated when no significant actor or part of the population considers re-negotiating the democratic rules of the game. The stabilization of democracy thus implies that "democracy becomes so broadly and profoundly legitimate among citizens that it is very unlikely to break down" (Diamond, 1994, p. 15; Miller, White, \& Heywood, 1997; see also Plasser, Ulram, \& Waldrauch, 1998; Plattner \& Diamond, 1996). In Easton's terminology, the democratic regime needs to generate diffuse support, an affective orientation referring "to evaluations of what an object is or represents - to the general meaning it has for a person" (Easton, 1975, p. 444). This also means that elite and mass support for democratic institutions does not stem from pragmatic compliance or vested interests, but from deeply entrenched values - thus scandals or economic difficulties do not fundamentally affect citizens' regime preferences, and electoral defeat or victory do not affect elites' regime preferences (Dryzek \& Holmes, 2002, p. 9; Linz \& Stepan, 1996, p. 16). In these approaches, cultural changes result from processes of modernization, with certain social and economic developments viewed as 
necessary requisites for the promotion and sustainability of the democratization process. Economic development is considered a crucial criterion, performing functions essential to the consolidation of democracy. Among others, these include allowing for the development of a middle class, encouraging the emergence of a vibrant civil society, decreasing levels of economic inequality, and accompanying the rise of education levels (Fish, 1998; Lipset, 1994, pp. 2-3; Przeworski, Alvarez, Cheibub, \& Limongi, 1996).

Drawing on this academic tradition, a branch of post-communist studies emphasise the path-dependency of various CEE trajectories, tracing the effect of country-specific legacies on the social, political and economic developments of the 1990s. A share of these argue that the state and civil society structures of the pre-1989 era affected post-socialist paths of extrication from communist rule, including elite negotiations and the resulting institutional arrangements of the early 1990s (Bunce, 2003; Kitschelt et al., 1999; Stark \& Bruszt, 1998). Subsequent developments in these democracies were also associated with the legacies of communist rule. For example, scholars examined the influence of communist regime types on the shape and representativeness of emerging patterns of party competition in Poland, Hungary and the Czech Republic (Kitschelt et al., op. cit). Wittenberg analysed the instrumental role of church institutions in socialist Hungary for the survival of pre-communist conservative political identities in post-communist times (Wittenberg, 2006). Others examined how networks of economic ties under socialism conditioned democratic governance and economic policy-making after 1989 (Stark \& Bruszt, 1998).

These approaches to democratic consolidation were criticised for not specifying the mechanisms by which political culture is transformed, and risks of democratic erosion subsequently reduced (Schedler, 1998, p. 104). Especially compared to the rational- 
institutionalist model, culturalist approaches lack analytical clarity. Certainly, many of the processes discussed by culturalist approaches - economic growth, the institutionalization of party systems, the development of mass education, the growth of civil society, etc. - are likely to play a role in the transformation of mass and elite attitudes. However, as summarized by Hanson, "modernization theory contains no compelling causal mechanism that might satisfactorily explain the cultural correlations it emphasizes" (Hanson, 2001, p. 132). In other words, while correlations may be established between given economic, social or political trends and the length of survival of democratic regimes, the processes that effectively link these macro-phenomena to the diffusion of mass support for democratic institutions remain both under-theorized and empirically under-investigated (Dryzek \& Holmes, 2002, p. 16; Kubik, 2003, pp. 318-322). As a result, how culture can itself evolve or integrate different elements, for instance, by becoming more democratic, is also difficult to apprehend. These elements led to deterministic arguments, where culture "descends from heaven to influence the course of history" (Haughton, 2005, p. 6), and where phenomena are explained with reference to a country's inalterable traditions. For instance, the idea that nationalistic and populist tendencies in CEE symbolise the 'return of the repressed' is widespread, these traits often being presented as long-lasting features of immature political cultures (Baer, 2001, p. 109; Ignatieff, 1993; Minkenberg, 2002, p. 358).

\section{The performative role of partisan mobilization}

The first task of a culturalist understanding of democratic consolidation would be to integrate the role of agency in processes of democratic change. This section identifies parties in their functions of citizen mobilization as key agents that contribute to such transformations. These organizations mediate between citizens and the state in a 
democratic polity; they channel popular demands and account for their execution. The strategies they use to mobilize citizens will thus shape citizens' perceptions of the democratic process, and more widely contribute to promote or undermine democratic norms within society at large.

Democratic theorists recently took an interest in this socializing role of institutions of representation in general, and of parties in particular (see especially Mansbridge, 2003; Muirhead, 2006; Rosenblum, 2008; Saward, 2010; Urbinati, 2006; White \& Ypi, 2010, 2011; Young, 2000). These scholars posit that representatives have agency in how they chose to represent citizens. Because constituents never offer themselves as a homogenous, predefined entity with a clear and encompassing set of interests, parties need to interpret what these interests are and make choices as to how they should be represented (Saward, 2010; Young, 2000, p. 126). As emphasised by Saward, representation as an activity "centrally involves offering constructions or images of constituents to constituents and audiences", and is thus primarily about "the active making of symbols or images of what is to be represented" (Saward 2010, pp. 14-15).

This is consequential for citizens themselves, and their self-identification. Citizen identities are conceived here not as fixed and pre-existing to representation, but as malleable and influenced by its processes. Crucially, “(p)arties do more than organize beliefs, interests, attitudes for political purposes. They discover and define politically relevant differences (...)" (Muirhead \& Rosenblum, 2006, p. 103). There is then a strong performative dimension to a successful act of representation. In other words, when constituents are effectively mobilized by parties, they not only recognise themselves in the images that representatives offer, but are also constituted and influenced by these images. 
This conception runs counter a general tendency in electoral and party studies that views political cleavages as the direct translation of social divisions. As expressed by Disch, representation "aims, then, not to reproduce a state of affairs but to produce an effect: to call forth a constituency by depicting it as a collective with a shared aim" (Disch, 2011, pp. 107-108; see also Sartori, 1968).

It is important to consider this creative dimension of partisan mobilization in relatively young democracies. In early $20^{\text {th }}$ century Western Europe, party systems structured how generations of citizens engaged with and understood politics, and this by forging strong normative projects around existing social cleavages (Campbell, Converse, Miller, \& Stokes, 1960; Rokkan \& Lipset, 1967). Similarly, the post-communist context is one in which new cleavages were defined and new political identities emerged. In this process, the attempts of parties to represent citizens and mobilize them around competing platforms will have had a strong influence on the stabilization of political identities. In the wake of regime changes, however, it is not only the definition of constituencies and partisan affiliations that is at stake: there also exists a broader struggle over re-defining the identity of the community as a whole. As emphasised by Jowitt, the end of communism created a "genesis environment," characterized by "the dissolution of existing boundaries and related identities and the corresponding potential to generate novel ways of life" (Jowitt, 1992, p. 266). ${ }^{17}$ With the end of decades of socialist rhetoric and the economic turmoil of the post-1989 years, leaders were given a golden opportunity to satisfy the yearning of these transitioning polities for narratives and myths (Tismaneanu, 1998).

$17 \mathrm{Or}$, as formulated by Offe, "post-communist societies have had to make a decision as to "who 'we' are; that is, a decision on identity, citizenship, and the territorial as well as social and cultural boundaries of the nation-state" (Offe, 2004, p. 505). 
If parties socialize citizens, then democratic consolidation as a radical form of cultural change is also dependent on the commitment of mainstream elites to democratic norms, and on the strategies parties deploy to mobilize citizens on the basis of these commitments. As Jowitt continues in his diagnosis of the post-1989 condition, "for a new way of life to assert itself, a social minority must completely identify with and accept an imperative task (...) for a critical period of time during which new elites, practices, organizations institutionally coagulate" (Jowitt, 1992, pp. 267-268). Jackson provides an example of such processes of elite legitimation in his analysis of the civilizational discourse of American and German elites in post-war Germany (Jackson, 2006). Demonstrating the importance of elite rhetoric in times of radical political change, he insists that "enormous flows of resources and reconfigurations of political practice require justification, and absent (elites') rhetorical deployments (...) it is unlikely that the resulting policies and institutions would have taken the form that they ultimately did" (Jackson, 2006, p. ix). Establishing the superiority of democracy as a 'novel way of life' in CEE will similarly require that elites legitimate the new regime through the public deployment of rhetoric.

Building on cultural theories of democratization and new theories of political representation, this section argued that party strategies of citizen mobilizattion have a central role in encouraging or deterring democratic forms of cultural change. On this basis, the last part of the paper outlines a three-fold research agenda for studying the influence of such party-citizen interactions on processes of democratic consolidation. 


\section{Studying democratic consolidation: a research agenda}

The following sets out a research agenda for studying the role of parties in processes of democratic change. Broadly speaking, it defends the need to conceive political culture in newly-formed democracies not as a static set of psychosocial traits, but as a 'tool-kit' open to political agents for re-interpretation and transformation. This is the semiotic understanding of culture prevalent in the field of political ethnography and, more generally, in studies adopting an interpretive standpoint. Gamson, for instance, defines culture as "the systems of signs available for talking, writing and thinking about political objects: the myths and metaphors, the language and idea elements, the frames, ideologies, values and condensing symbols" (Gamson, 1988, p. 220). ${ }^{18}$ Conceived in this way, political culture may be studied by observing the use that agents make of this system of signs. Interpretive methodologies thus take as their object the meaning-making activities of individuals, divided between methods focusing on language and discourse - for instance discourse analysis, dialogical analysis, or mentalism - and methods that focus on practice, mainly participant forms of observations (Bevir \& Rhodes, 2010; Schatz, 2009; White, 2009; Yanow \& Schwartz-Shea, 2006). Studying discourse and practice has clear advantages over alternative methods, such as surveys for instance. It allows exploration of socially shared knowledge, reasoning and argument, and more generally, political meaning in construction (Belzile \& 0berg, 2012, p. 467; Marková, 2007; White, 2011, pp. 40, 45). In the present case, such methods account more closely for the meaning elites and citizens

\footnotetext{
18 Such a conception may be opposed to the classic definition of political culture, defended for instance in Almond and Verba's study of Civic Culture (Almond \& Verba, 1963). Here culture is theorized as a "syndrome of attitudes, (...) a people's predominant beliefs, attitudes, values, ideals, sentiments, and evaluations about the political system of its country, and the role of the self in the system" (Kubik, 2003, pp. 321-322). The widespread reliance on survey data for measuring political culture in value-based approaches to democratic consolidation reveals the predominance of such a conception of culture as a psycho-social reality.
} 
place on the signifier 'democracy,' and this within the wider web of signs in which this term finds its meaning (Dryzek \& Holmes, 2002).

On this basis, three interrelated topics would warrant further empirical research: the degree of commitment of mainstream party elites to democratic norms; their discursive and organizational strategies to mobilize citizens; and the degree to which parties contribute to citizen socialization in deploying these strategies.

\section{Elite commitments to the democratic process}

As stressed above, a deeper commitment of mainstream elites to the democratic process ensures that these exercise restraint when faced with an opportunity to undermine democracy to their own benefit. Gathering empirical data on this issue is necessarily difficult. Given the widespread international consensus on the positive value of democracy, elites are unlikely to be explicit about these commitments. ${ }^{19}$ Most autocratic leaders hold token elections and claim to act in the name of popular sovereignty to maintain a form of domestic and international legitimacy (Zakaria, 1997). In CEE, the existence of a widespread elite consensus on the objective of EU accession in the 1990s precluded any explicit advocacy of alternatives to democracy (Batory, 2008; Vachudova, 2008). Surveys that rely on respondents' approval or disapproval of very general categories such as 'democracy' and 'authoritarianism,' would be, therefore, typically inappropriate for studying commitments to democratic norms. Not only would elites be likely to answer these surveys in a way they deem socially desirable, but these answers would say little about what individuals understand by these categories (Dryzek \& Holmes, 2002). As

19 Recently, the Hungarian Prime Minister has, nevertheless, made statements that more explicitly opposed liberal democracy as a regime, defending the need for his party "to abandon liberal methods and principles of organizing a society" and to build an "illiberal state" in Hungary (Orbán, 2014). 
developed below, elite public discourse may provide implicit expressions of loyalty or disloyalty to democratic norms (Linz, 1978, pp. 28-38), but given the weight of EU constraints these will only offer limited indications. The same logic applies to one-on-one elite interviews, in which respondents will not openly acknowledge whether they are committed to the democratic process (Steiner, Bächtiger, Spörndli, \& Steenbergen, 2004, p. 54; White, 2011, p. 45).

If elite discourse can be expected to vary depending on the context and audience that is being addressed, studying such variations would provide a first indication of these norms. One would then need to compare instances of elite discourse that take place in environments that are more or less constrained by international norms, or in other words, observe whether elites are more explicit about undemocratic commitments where costs of doing so are lower. Comparing discourse destined for an international public to one destined to a domestic public may provide such indications, especially when the national language is not widely spoken abroad. Similarly, one could compare the public declarations of elites to the ones they use in more private settings, or among their peers. Participant observation, a method defined as "the process of learning through exposure to or involvement in the day-to-day or routine activities of participants in the researcher setting", may be one way of getting closer to such private forms of discourse (Schensul \& LeCompte, 1999). Immersion in the internal life of a given party, for instance spending an extended period of time within a party headquarter or a ministry, would typically allow access to group discussions among elites where more explicit expressions of democratic or undemocratic commitments would be evident (see Belzile \& 0berg, 2012, p. 467; Bevir \& Rhodes, 2010; Marková, 2007; White, 2011, pp. 40,45). Given the absence of a common 
standard in the literature for evaluating such commitments, country comparisons are also warranted in this domain. Comparing the nature and level of democratic norms in new and old European democracies would be especially crucial, as this would provide information on the degree to which a history of democracy matters to the value-systems of party leaderships.

\section{Discursive and organizational strategies of citizen mobilization}

As previously emphasised, to undermine democracy's 'procedural minimum' mainstream parties with a disloyal leadership need to win a large parliamentary majority, and thus to rally a substantial part of the electorate. Empirical work is thus warranted on how such parties can successfully mobilize within the confines of a democratic constitutional framework, and in the context of a constrained international environment. Two dimensions of these strategies would deserve specific attention. First, the ideational component, or in other words, the platforms on which mainstream parties mobilize; and second, the organizational component, that is the networks, events, and resources that parties rely on to increase their societal reach.

As mainstream parties with a disloyal leadership cannot be explicit about their lack

of democratic commitment, alternative discursive strategies can be expected that will render their claim to power more acceptable in the domestic and international arena. Populism is a likely candidate, precisely because it carries an ambivalent democratic message. The populist speaker claims to act in the name of the 'People', and yet denies the 
legitimacy of alternative claims to citizen representation. ${ }^{20}$ One of the distinguishing features of CEE populism is that it frequently affects the political mainstream, in contrast to Western European party systems where such rhetoric tends to be contained at the fringes of party systems (Mudde, 2002). Concerning Fidesz, existing studies show that the party started deploying such rhetoric prior to the 1998 election campaign, and radicalized continuously until 2010. Fidesz's discourse repeatedly depicts the nation as a unitary actor that can only legitimately be represented by the Fidesz, and their opposition as a corrupt and elitist clique that tramples on the nation's interests (Bozóki, 2008; Bozóki \& Kriza, 2008, p. 217; Centre for fair political analysis, 2013; Enyedi, forthcoming; Palonen, 2006; 2009, pp. 322-324). ${ }^{21}$ More systematic comparative work across the region would be required to map the type of discursive strategies mainstream parties deploy, and the degree to which they can be labelled as populist (for an operationalization, see DeeganKrause \& Haughton, 2009). Attention should also be given to the evolution of these discursive strategies over time, and the circumstances under which they prove successful

\footnotetext{
${ }^{20}$ Because populism defends popular sovereignty as a high but neglected ideal, some scholars have described this type of rhetoric as a radical form of democratic discourse, one that could provide a useful corrective to the increasingly professionalised politics of Western Europe (Canovan, 1999; Mény \& Surel, 2002; Mouffe, 2005). Such a discourse nevertheless sets the 'People' as an idealized, unitary actor that can only be represented by the populist party, and that needs to be defended against its enemies, generally a corrupt elite usurping the people's political power (Panizza, 2005; Stanley, 2008). By negating horizontal cleavages within society and the validity of party pluralism, populism therefore also takes on authoritarian connotations, and this especially when it is deployed in the mainstream of a given party system.

${ }^{21}$ Following the electoral defeat of his party in 2002 for instance, Fidesz leader Viktor Orbán declared "(..) those of us who are present on this square are not, and cannot be, in opposition, because the Homeland cannot be in opposition" (Enyedi, forthcoming). More recently, speaking about the 'liberal-left' (balliberális) elites at the commemoration of the 1956 uprising in October 2013, Prime Minister Viktor Orbán declared for instance "(d)uring the (early 1990s) period of transition they silently knitted ties with foreign forces, giving them a free pass to the country's resources and wealth (...) Those who earlier indebted the country till the neck, they crawled back, and took away the possibility for us, Hungarians, to decide on our own lives"(Orbán, 2013).
} 
for mobilizing citizens. In Hungary for instance, the deep political and economic crisis under MSzP's 2006-2010 mandate was pivotal in giving traction to Fidesz's appeals. ${ }^{22}$

Citizen mobilization also has an organizational dimension. Beyond the platforms parties defend, they deploy means to communicate their message and achieve public visibility. In established democracies, parties progressively ceased to rely on membership to gather funds and diffuse their ideas from the 1960s onwards, and now depend far more heavily on state resources and the mass media for these purposes (Katz \& Mair, 1995, 2009). Given the weak ties CEE parties had with civil society in the early 1990s, they also established statuses that minimized their dependence on private donations and membership fees, gave a strong role to state funding, and tightly regulated campaign advertisement (Kopecký, 2006). Despite the steep decline in the membership numbers of Western European parties, these numbers still remain far higher than in post-communist Europe (Biezen van, Poguntke, \& Mair, 2012). At the same time, studies show that CEE parties that achieved societal anchorage - namely through the development of an extensive network of local branches and their membership base - have a significant advantage over other parties in mobilizing popular support during elections (Tavits, 2012).

More empirical research is thus warranted to explain variations in the organizational models of parties across the region, and explore the reasons why some were more successful than others at developing a strong social basis. The Hungarian party system is a case in point. While the ageing membership of MSzP declined steadily since the

\footnotetext{
22 The international economic crisis hit the country particularly hard in 2008, and was coupled with a local, political crisis. On May 26, 2006, Prime Minister Ferenc Gyurcsány gave a confidential speech to MSzP members of Parliament in Balatonőszöd, where he emphasised that his party had lied to the Hungarian public about the state of the economy prior to the 2006 elections. The speech was leaked and diffused on Magyar Rádio on September 17. This sparked a wave of riots and popular discontent, the governing party's popularity dropping to a record low. With the 2008 international crisis, the country had to accept a $\$ 25$ billion guarantee package from the IMF, and to initiate a second wave of drastic austerity measures.
} 
early 1990s, Fidesz party members increased from less than 5000 in 1990 to over 40000 in 2011 (Saltman, 2014, pp. 105-106). In parallel, the number of local party branches of Fidesz also increased between 2001 and 2005 from around 400 to 1050 (Enyedi \& Linek, 2008, pp. 462-463). ${ }^{23}$ The electoral advantages that such a member-based organization provides to parties have been under-researched in the case of CEE. Fidesz achieved high visibility in the public space of major cities thanks to its dense network of supporters, organizing regular town-hall meetings, public discussions, and demonstrations. Spectacular actions included the coordination of a number of mass rallies that united over 100000 participants in 2006, and the organization of four large-scale petitions that collected close to a million signatures (Enyedi \& Linek, 2008, p. 464). It remains to be established how these strategies served its 2010 landslide electoral victory.

\section{The socializing role of parties}

If the long-term consolidation of democracy is dependent on parties promoting democratic norms among the broader citizenry, disloyal parties will also seek to diffuse to the broader public their lack of democratic commitment. This process serves parties in a number of ways. It may expand the party's capacity for mobilizing citizens, first through the radicalization of its existing basis of support, and second through expanding its reach to new constituencies. The diffusion of non-democratic norms will also make institutional reforms more acceptable to the broader population, and limit the risks of resistance to such changes. Socialization may thus increase the chances of disloyal actors remaining in power once the rules of the political game are modified to their advantage.

23 This is all the more remarkable given that, as emphasised by Enyedi and Linek, this growth took place mostly during periods where Fidesz was in opposition, suggesting genuine popular mobilization rather than the development of clientelistic networks (Enyedi \& Linek, 2008, pp. 462-463) 
Empirical research should examine how disloyal leaderships draw on the existing preferences of citizens, and the extent to which they also socialize citizens into nondemocratic norms. Pre-existing political identities - values, interests and group membership - necessarily limit the creative dimension of partisan representation (Enyedi, 2005). More broadly, the ability of parties to mobilize around a project is dependent not only on the leader's agency, but also on what Gamson terms the 'cultural resonance' of the party's broader message (Gamson, 1992, p. 135). In this sense parties are constrained by a pre-existing context, a context that may not be favourable to the emergence of pluralistic norms of political competition. This opens up a wealth of other relevant questions, for instance whether certain types of mobilization strategies are more 'creative' than others over time; whether certain groups in a given population are more influenced by these strategies than others; or whether socializing effects are stronger in new rather than in established democracies.

A number of disciplines relying on a variety of different methods explore these types of questions, and may provide inspiration for future research. For instance, the recent 'contextualist' turn in public opinion and political psychology studies is providing mounting evidence that citizens opinions do shift according to how parties frame issues (Chong \& Druckman, 2007; Druckman, 2004; Manza \& Cook, 2002.; Sniderman \& Theriault, 2004). For example Chong and Druckman demonstrate, using experimental data, that party frames can moderate ideological extremes and that the 'relative strength' of these frames does affect citizens' engagement with them (Chong \& Druckman, 2007). While these types of dynamics are under-researched in CEE, there is also evidence that they strongly operate in newly-found democracies. Relying on in-depth interviews and participant observation 
methods to study youth activism in contemporary Hungary, Saltman shows that parties are core institutions of political socialization among younger Hungarian cohorts (Saltman, 2014). But quantitative methods may also be appropriate for such an endeavour. For instance, using surveys and voting data, Enyedi defended the relevance of an approach to cleavage formation in CEE that starts with the "strategic calculations of the political actors and not with the distribution of the preferences in the society" (Enyedi, 2005, p. 699). According to him, the ideological trajectory of Fidesz towards a form of national-populism since the mid-1990s contributed to attitudinal changes within Hungarian society, encouraging especially the development of authoritarian values among younger generations.

\section{Conclusion}

This paper offered a critical reading of rational-institutionalist models of democratic consolidation in the light of the erosion of the 'procedural minimum' of Hungarian democracy since 2010. The conditions set out by these models - well-designed institutions and sustained political competition - are insufficient for ensuring a democratic regime against erosion. In order to understand Fidesz's reforms, two additional elements should be considered: the importance of mainstream parties' deeper commitments to democracy, and the pivotal role of party strategies of citizen mobilization in the consolidation of young democracies. Drawing on these insights, the paper revisited cultural theories of democratic consolidation that emphasise the importance of diffuse support for the democratic regime among the broader citizenry. Importantly, parties do not simply reflect pre-existing 
political preferences but contribute to shape these, thus taking on a role as agents of socialization in their attempts to mobilize citizens. These insights call for a broader recourse to interpretative methods for studying these strategies and their consequences in newly-found democracies.

Acknowledgements: The author thanks Tim Luecke and three anonymous reviewers for their generous and constructive feedback. Previous versions of this paper have benefited from presentations at Sciences Po, Paris (CERI, Conference on Russia and Central Europe, 11-12 June 2013) and the European University Institute, Florence (Workshop on Parties and Democracy in Post-communist Europe, 18-19 September 2014).

\section{References}

Ágh, A. (2012). Report on Democracy, Freedom and liberty in Central and Eastern Europe. Foundation for European Progressive Studies. http://www.fepseurope.eu/en/news/316 report-on-democracy-freedom-and-liberty-in-central-and-easterneurope

Alevizakos, V. W. (2008). Party strategies and the process of democratic consolidation in Southern and Central Europe. (PhD thesis), London School of Economics and Political Science.

Alexander, G. (2001). Institutions, Path Dependence, and Democratic Consolidation. Journal of Theoretical Politics, 13(3), 249-269.

Alexander, G. (2002a). Institutionalized uncertainty, the rule of law, and the sources of democratic stability. Comparative Political Studies, 35(10), 1145-1170.

Alexander, G. (2002b). The sources of democratic consolidation. Ithaca: Cornell University Press.

Almond, G. A., \& Verba, S. (1963). The civic culture: Political attitudes and democracy in five nations. Princeton N.J.: Princeton University Press.

Baer, J. (2001). Boxing and Politics in Slovakia: "Meciarism" - roots, theory, practice. Democratization, 8(2), 97-116.

Bánkuti, M., Dombos, T., Fleck, Z., Halmai, G., Rozgonyi, K., Majtényi, B., . . Uit, R. (2012). Amicus Brief for the Venice Commission on the Transitional Provisions of the Fundamental Law and the Key Cardinal Laws. Retrieved September 8, 2014, from http://lapa.princeton.edu/hosteddocs/hungary/Amicus Cardinal Laws final.pdf 
Batory, A. (2008). The politics of EU accession : ideology, party strategy and the European question in Hungary. Manchester: Manchester University Press.

Belzile, J., \& 0berg, G. (2012). Where to begin? Grappling with how to use participant interaction in focus group design. Qualitative research, 12(4), 459-472

Benoit, K. (1996). Hungary's two - vote' electoral system. Representation, 33(4), 162-170.

Bevir, M., \& Rhodes, R. A. W. (2010). The state as cultural practice. Oxford: Oxford University Press.

Biezen van, I., Poguntke, T., \& Mair, P. (2012). Going, Going...Gone? The Decline of Party Membership in Contemporary Europe. European Journal of Political Research, 51(1), 24-56.

Birch, S. (2001). Electoral Systems and Party Systems in Europe East and West. Perspectives on European Politics and Society, 2(3), 355-377.

Bozóki, A. (2008). Consolidation or Second Revolution? The Emergence of the New Right in Hungary',. Journal of Communist Studies and Transition Politics, 24(2), 191-231.

Bozóki, A. (2013). Access to Electoral Rights - Hungary. European Union Democracy Observatory, Robert Schuman Centre for Advanced Studies, RSCAS/EUDO-CIT-ER 2013/19.

Bozóki, A., \& Kriza, B. (2008). The Hungarian semi-loyal parties and their impact on democratic consolidation. In A. Blasko \& D. Januauskiene (Eds.), Political transformation and changing identities in Central and Eastern Europe (pp. 215-242). Washington D.C.: Council for Research in Values and Philosophy.

Bozóki, A. S., \& Ishiyama, J. T. (Eds.). (2002). The communist successor parties of Central and Eastern Europe. Armonk NY: M.E. Sharpe.

Brada, J. C. (1996). Privatization is Transition--Or is it? The Journal of Economic Perspectives, 10(2), 67-86.

Buckley, N. (2012, July 8). Fears grow for democracy in Romania, Online. Financial Times [online]. Retrieved from http://www.ft.com/cms/s/0/e3f4a24a-c901-11e1-a76800144feabdc0.html

Bunce, V. (2003). Rethinking Recent Democratization: Lessons from the Postcommunist Experience. World Politics, 55(January 2003), 167-192.

Campbell, A., Converse, P. E., Miller, W. E., \& Stokes, D. E. (1960). The American voter. New York: Wiley.

Canovan, M. (1999). Trust the People! Populism and the Two Faces of Democracy. Political Studies, 47(1), 2-16.

Carothers, T. (2002). The end of the transition paradigm. Journal of Democracy, 13(1), 5-21.

Casal Bértoa, F., \& Mair, P. (2010). Two decades on: how institutionalized are the postcommunist party systems? . EUI Working Paper, 3.

Centre for fair political analysis. (2013). The anatomy of the Hungarian right. Retrieved September 24, 2014, from http://meltanyossag.hu/content/files/Anatomy of the Hungarian Right 120630.pdf

Chong, D., \& Druckman, J. (2007). Framing Public Opinion in Competitive Democracies. American Political Science Review, 101(101), 637-655.

Clark, T. D. (2002). Beyond post-communist studies: political science and the new democracies of Europe. Armonk N.Y.: M.E. Sharpe.

Cohen, S. J. (1999). Politics without a past : the absence of history in post-communist nationalism. Durham, N.C.: Duke University Press.

Council of Europe. (2013). Adopted Opinions for "Hungary". Retrieved July 23, 2014, from $<$ http://www.venice.coe.int/webforms/documents/?country=17\&year=all>

Council of Europe Commissioner for Human Rights. (2011). Opinion of the Commissioner for Human Rights on Hungary's media legislation in light of Council of Europe standards on 
freedom of the media, CommDH(2011). Retrieved July 29, 2014, from https://wcd.coe.int/com.instranet.InstraServlet?Index=no\&command=com.instranet.CmdB lobGet\&InstranetImage $=1902982 \&$ SecMode $=1 \&$ DocId $=1702724 \&$ Usage $=2$

Dahl, R. A. (1971). Polyarchy : participation and opposition. New Haven: Yale University Press.

Dalton, R. J., \& Wattenberg, M. P. (2000). Parties without partisans : political change in advanced industrial democracies. Oxford: Oxford University Press.

Dani, M. (2013). The 'Partisan Constitution' and the corrosion of European constitutional culture. LSE 'Europe in Question' Discussion Paper Series, 68(November).

Deegan-Krause, K., \& Haughton, T. (2009). Toward a more useful conceptualization of populism: types and degrees of populist appeals in the case of Slovakia. Politics and Policy, 37(4), 821841.

Di Palma, G. (1990). To craft democracies: an essay on democratic transitions. Berkeley: University of California Press.

Diamond, L. J. (1994). Toward Democratic Consolidation. Journal of Democracy, 5(3), 4-17.

Dimitrova-Grajzl, V., \& Simon, E. (2010). Political Trust and Historical Legacy: The Effect of Varieties of Socialism. East European Politics \& Societies.

Disch, L. (2011). Toward a Mobilization Conception of Democratic Representation. American Political Science Review, 105(01), 100-114.

Druckman, J. N. (2004). Political Preference Formation: Competition, Deliberation, and the (Ir)relevance of Framing Effects. American Political Science Review, 98(4), 671-686.

Dryzek, J., \& Holmes, L. (2002). Post-Communist democratization: political discourses across thirteen countries. Cambridge: Cambridge University Press.

Easton, D. (1975). A Re-Assessment of the Concept of Political Support. British Journal of Political Science, 5(4), 435-457.

Enyedi, Z. (2005). The role of agency in cleavage formation. European Journal of Political Research, 44(5), 697-720.

Enyedi, Z. (2006). Party politics in post-communist transition. In R. S. Katz \& W. J. Crotty (Eds.), Handbook of party politics (pp. 228-238). London: SAGE.

Enyedi, Z. (forthcoming). Plebeians, citoyens and aristocrats or where is the bottom of bottom-up? The case of Hungary. In H. Kriesi \& T. Pappas (Eds.), Populism in the Shadow of the Great Recession (pp. 338-362): ECPR Press.

Enyedi, Z., \& Linek, L. (2008). Searching for the Right Organization. Party Politics, 14(4), 455-477.

European Commission. (2003). Comprehensive monitoring report on Hungary's preparations for membership. $\quad$ Retrieved September 7, 2014, from http://ec.europa.eu/enlargement/archives/pdf/key documents/2003/cmr hu final en.pdf

European Parliament. (2013). Report on the Situation of Fundamental Rights: Standards and Practices in Hungary ('Rui Tavares Report'). Retrieved July 23, 2014, from < http://www.europarl.europa.eu/sides/getDoc.do?pubRef=-//EP//TEXT+REPORT+A7-20130229+0+DOC+XML+V0//EN >

Evans, G., \& Whitefield, S. (1998). The Structuring of Political Cleavages in Post-Communist Societies : the Case of the Czech Republic and Slovakia. Political Studies, XLVI, 115-139.

Evans, G., \& Whitefield, S. (2000). Explaining the formation of electoral cleavages in postcommunist democracies. In H.-D. Klingemann, E. Mochmann \& K. Newton (Eds.), Elections in Central and Eastern Europe: The First Wave (pp. 36-70). Berlin: Sigma.

Fish, S. M. (1998). Democratization's requisites: the post-communist experience. Post-soviet affairs, 14(3), 212-247. 
Freedom House. (2012). Nations in transit 2012. Retrieved 23 July, 2014, from http://www.freedomhouse.org/report/nations-transit/nations-transit-2012

Freedom House. (2014a). Nations in Transit 2014 Methodology. Retrieved September 7, 2014, from http://freedomhouse.org/sites/default/files/Methodology Proof1.pdf

Freedom House. (2014b). Nations in transit 2014, Eurasia's rupture with democracy. Retrieved 23 July, 2014, from http://www.freedomhouse.org/sites/default/files/NIT2014 booklet WEBSITE.pdf

Freedom House. (2014c). Nations in Transit country report, Hungary. Retrieved September 7, 2014, from http://www.freedomhouse.org/report/nations-transit/2014/hungary .VAyXaqhLHJ4

Gamson, W. A. (1988). Political discourse and collective action. In B. Klandermans, H. Kriesi \& S. Tarrow (Eds.), International social movement research, vol. 1, From structure to action: comparing social movement research across cultures (pp. 219-246). Greenwich: JAI press.

Gamson, W. A. (1992). Talking politics. Cambridge England: Cambridge University Press.

Gofas, A., \& Hay, C. (Eds.). (2007). The role of ideas in political analysis : a portrait of contemporary debates. London :: Routledge.

Grabbe, H. (2006). The EU's transformative power : Europeanization through conditionality in Central and Eastern Europe. Basingstoke ;: Palgrave Macmillan.

Grzymala-Busse, A. (2002). Redeeming the communist past : the regeneration of communist parties in East Central Europe. Cambridge: Cambridge University Press.

Grzymala-Busse, A. (2007). Rebuilding Leviathan : party competition and state exploitation in postcommunist democracies. Cambridge; New York: Cambridge University Press.

Grzymalala-Busse, A., \& Innes, A. (2003). Great Expectations: The EU and Domestic Political Competition in East Central Europe. East European Politics \& Societies, 17(1), 64-75.

Hanley, S., Szczerbiak, A., Haughton, T., \& Fowler, B. (2008). Sticking Together, Explaining Comparative Centre-Right Party Success in Post-Communist Central and Eastern Europe. Party Politics, 14(4), 407-434.

Hanson, S. (2001). Defining democratic consolidation. In R. Anderson, S. Fish \& P. Roeder (Eds.), Postcommunism and the theory of democracy (pp. 126-151). Princeton N.J.: Princeton University Press.

Haughton, T. (2005). Constraints and opportunities of leadership in post-communist Europe. Ashgate: Ashgate.

Hay, C. (2007). Why we hate politics. Cambridge: Polity Press.

Hungarian Central Statistical Office. (2013). A nonprofit szektor legfontosabb jellemzői 2012-ben. Retrieved September 8, 2014, from http://www.ksh.hu/docs/hun/xftp/stattukor/nonprofit/nonprofit12.pdf

Hungarian National Election Office. (2010). 2010 Official Election Results. Retrieved September 8, 2014, from http://www.valasztas.hu/hu/parval2010/354/354 0 index.html

Hungarian Parliament. (1989). Act No. XX of 1949 (as amended). Retrieved September 7, 2014, from http://lapa.princeton.edu/hosteddocs/hungary/1989-90 constitution english.pdf

Hungarian Parliament. (2011). The Fundamental Law of Hungary, as amended on September 16, 2013. from http://www.kormany.hu/download/e/02/00000/The New Fundamental Law of Hungary.pdf

Huntington, S. P. (1991). The third wave: democratization in the late twentieth century. Norman: University of Oklahoma Press.

Ignatieff, M. (1993). Blood and belonging. Toronto: Viking. 
Innes, A. (2002). Party Competition in Postcommunist Europe: The Great Electoral Lottery. Comparative Politics, 35(1), 85-104.

Ishiyama, J. T. (2001). Sickles with Roses: The Successor Parties and Democratic consolidation in post-communist politics. In P. G. Lewis (Ed.), Party development and democratic change in post-Communist Europe : the first decade (pp. 32-52). London: Frank Cass.

Ishiyama, J. T. (Ed.). (1999). Communist successor parties in post-communist politics. Commack N.Y.: Nova Science Publishers.

Jackson, P. T. (2006). Civilizing the enemy : German reconstruction and the invention of the West. Ann Arbor: Ann Arbor : University of Michigan Press.

Jasiewicz, K. (2007). The political-party landscape. Journal of Democracy, 18(4), 26-33.

Jowitt, K. (1992). New world disorder: the Leninist extinction. Berkeley: University of California press.

Katz, R. S., \& Mair, P. (1995). Changing Models of Party Organization and Party Democracy: The Emergence of the Cartel Party. Party Politics, 1(1), 5-28.

Katz, R. S., \& Mair, P. (2009). The Cartel Party Thesis : A Restatement. Perspectives on Politics, 7(4), 753-766.

King, C. (2000). Post-postcommunism - Transition, Comparison and the End of "Eastern Europe". World Politics, 53, 143-172.

Kitschelt, H., Markowski, R., Mansfeldova, \& Toka, G. (1999). Post-communist party systems : competition, representation, and inter-party cooperation. Cambridge: Cambridge University Press.

Kopecký, P. (2006). Political Parties and the State in Post-Communist Europe: The Nature of Symbiosis. Journal of Communist Studies and Transition Politics, 22(3), 251-273.

Kopecký, P. (2007). Political parties and the state in post-communist Europe. London: Routledge.

Kopecký, P., \& Mudde, C. (2000). What has Eastern Europe taught us about the democratisation literature (and vice versa)? European Journal of Political Research, 37, 517-539.

Kornai, J. (2011, January 7). Taking Stock. Népszabadság. Retrieved from http://nol.hu/gazdasag/ianos kornai taking stock

Kovács, K., \& Tóth, G. A. (2011). Hungary's Constitutional Transformation. European Constitutional Law Review, 7.

Krasovec, A. (2001). Party and State in democratic Slovenia. In P. G. Lewis (Ed.), Party development and democratic change in post-Communist Europe : the first decade (pp. 93-106). London: Frank Cass.

Kubik, J. (2003). Cultural legacies of state socialism - History making and cultural-political entrepreneurship in postcommunist Poland and Russia. In G. Ekiert \& S. E. Hanson (Eds.), Capitalism and Democracy in Central and Eastern Europe: Assessing the Legacy of Communist Rule (pp. 317-351). Cambridge: Cambridge University Press.

Lewis, P. G. (2001a). Conclusion: party development and democratization in Eastern Europe. In P. G. Lewis (Ed.), Party development and democratic change in postCommunist Europe: the first decade (pp. 199-211). London: Frank Cass.

Lewis, P. G. (2001b). Introduction: Democratization and Political Change in PostCommunist Europe. In P. G. Lewis (Ed.), Party development and democratic change in post-Communist Europe: the first decade (pp. 1-15). London: Frank Cass.

Lewis, P. G. (2006). Party Systems in Post-communist Central Europe: Patterns of Stability and Consolidation. Democratization, 13(4), 562-583. 
Lijphart, A. (1992). Democratization and constitutional choices in Czecho-Slovakia, Hungary and Poland, 1989-1991. Journal of Theoretical Politics, 4(2), 207-223.

Linz, J. (1978). The breakdown of democratic regimes: crisis, breakdown, and reequilibration. Baltimore: Johns Hopkins University Press.

Linz, J., \& Stepan, A. (1996). Toward consolidated democracies. Journal of Democracy, 7(April), 14-33.

Linz, J., \& Valenzuela, A. (Eds.). (1994). The failure of presidential democracy. Baltimore: Johns Hopkins University Press.

Lipset, S. M. (1994). The Social Requisites of Democracy Revisited: 1993 Presidential Address. American Sociological Review, 59(1), 1-22.

Mair, P. (1997). What is Different About Post-Communist Party Systems? In P. Mair (Ed.), Party system change: Approaches and interpretations (pp. 175-198). Oxford: Clarendon Press.

Mansbridge, J. (2003). Rethinking Representation. The American Political Science Review, 97(4), 515-528.

Manza, J., \& Cook, F. L. (2002.). A Democratic Polity? Three Views of Policy Responsiveness to Public Opinion in the United States. American Politics Research, 30(6), 630-667.

Marková, I. (2007). Dialogue in focus groups: exploring socially shared knowledge. London: Equinox.

Markowski, R. (2001a). Democratic consolidation and accountability: news from Eastern and Central European democracies. In E. Wnuk-Lipinski \& R. Markowski (Eds.), Transformative paths in Central and Eastern Europe (pp. 47-72). Warsaw: Instytut Studiów Politycznych Polskiej Adamemii Nauk.

Markowski, R. (2001b). Party system institutionalization in New Democracies: Poland, a trend-setter with no followers. In P. G. Lewis (Ed.), Party development and democratic change in post-Communist Europe : the first decade (pp. 55-77). London: Frank Cass.

Mény, Y., \& Surel, Y. (2002). The Constitutive ambiguity of Populism Democracies and the populist challenge. Basingstoke: Palgrave.

Michnik, A. (2007, June 28). The Polish Witch-Hunt. The New York Review of Books. Retrieved from http://www.nybooks.com/articles/archives/2007/jun/28/the-polish-witchhunt/?pagination=false

Millard, F. (2004). Elections, parties, and representation in post-communist Europe. Basingstoke: Palgrave Macmillan.

Miller, W., \& White, S. (1998). Political Values Underlying Partisan Cleavages in Former Communist Countries. Electoral Studies, 17(2), 197-216.

Miller, W., White, S., \& Heywood, P. (1997). Values and political change in postcommunist Europe. New York: St. Martin's Press.

Minkenberg, M. (2002). The radical right in postsocialist Central and Eastern Europe: Comparative observations and interpretations. East European Politics and Societies, 16, 335-362.

Mishler, W., \& Rose, R. (1997). Trust, Distrust and Skepticism : Popular Evaluations of Civil and Political Institutions Societies in Post-Communist. The Journal of Politics, 59(2), 418-451.

Misztal, B. A. (1996). Trust in modern societies : the search for the bases of social order. Cambridge: Polity.

Mouffe, C. (2005). The 'End of Politics' and the Challenge of Right-wing populism. In F. Panizza (Ed.), Populism and the Mirror of Democracy. London: Verso. 
Mudde, C. (2002). In the name of the Peasantry, the Proletariat, and the People: Populism in Eastern Europe. In Y. Mény \& Y. Surel (Eds.), Democracies and the populist challenge. Basingstoke: Palgrave.

Muirhead, R. (2006). A Defense of Party Spirit. Perspectives on Politics, 4(4), 713-727.

Muirhead, R., \& Rosenblum, N. L. (2006). Political Liberalism vs. "The Great Game of Politics": The Politics of Political Liberalism. Perspectives on Politics, 4(01), 99-108.

Norwegian Helsinki Commitee. (2013). Democracy and Human Rights at stake in Hungary, The Viktor Orbán government's drive for centralisation of power. Retrieved 23, July 2014, from http://nhc.no/filestore/Publikasjoner/Rapporter/2013/Rapport 113 web.pdf

O'Donnell, G. (1996). Illusions about consolidation. Journal of Democracy, 7(2), 34-51.

O'Donnell, G., Schmitter, P., \& Whitehead, L. (1986). Transitions from authoritarian rule. Baltimore: Johns Hopkins University Press.

O'Dwyer, C. (2008). Re-stating Party Development in Central and Eastern Europe: A Response. Czech Sociological Review, 44(6), 1181-1188.

Offe, C. (2004). Capitalism by Democratic Design? Democratic Theory Facing the Triple Transition in East Central Europe. Social Research, 71(3), 501-528.

Olson, D. M. (1998). Party Formation and Party System Consolidation in the New Democracies of Central Europe. Political Studies, XLVI, 432-464.

Orbán, V. (2013). Speech for the comemoration of the 1956 uprising, October 23, 2013. Retrieved $\begin{array}{lll}\text { September 24, 2014, from } & \text { 24, }\end{array}$ http://www.miniszterelnok.hu/beszed/kozeledunk a valodi felszabadulas fele

Orbán, V. (2014). Speech at the Free University and Student Camp in Băile Tuşnad, Romania. Retrieved September 24, 2014, from http://www.kormany.hu/hu/a-miniszterelnok/beszedekpublikaciok-interjuk/a-munkaalapu-allam-korszaka-kovetkezik. English translation at: http://budapestbeacon.com/public-policy/full-text-of-viktor-orbans-speech-at-baile-tusnadtusnadfurdo-of-26-july-2014/

OSCE. (2002). Republic of Hungary, Parliamentary elections 7 and 21 April 2002, Final Report. $\begin{array}{llll}\text { Retrieved } & \text { September } & \text { 2014, from }\end{array}$ http://www.osce.org/odihr/elections/hungary/16177?download=true

OSCE. (2011). Analysis of the Hungarian Media Legislation. Tallinn University for the Organization for Security and Co-operation in Europe (OSCE), Office of the Representative on Freedom of the Media. Retrieved 29 July, 2014, from http://www.osce.org/fom/75990?download=true

OSCE. (2014). Hungary, Parliamentary Elections, 6 April 2014, OSCE/ODIHR Limited Election Observation Mission Final Report Retrieved September 8, 2014, from http://www.osce.org/odihr/elections/hungary/121098?download=true

Palonen, E. (2006). Reading Budapest: Political Polarization in Contemporary Hungary. (PhD in Ideology and Discourse), University of Essex, Unpublished PhD Thesis.

Palonen, E. (2009). Political Polarisation and Populism in Contemporary Hungary. Parliamentary Affairs, 62(2), 318-334.

Panizza, F. (2005). Introduction, Populism and the mirror of democracy Populism and the Mirror of Democracy. London: Verso.

Pharr, S. J., \& Putnam, R. D. (Eds.). (2000). Disaffected democracies: what's troubling the trilateral democracies? Princeton NJ: Princeton University Press.

Plasser, F., Ulram, P. A., \& Waldrauch, H. (1998). Democratic consolidation in East-Central Europe. New York: St. Martin's Press.

Plattner, M. F., \& Diamond, L. J. (Eds.). (1996). The global resurgence of democracy (2nd ed.). Baltimore: Johns Hopkins University Press. 
Political Capital. (2011). The New Hungarian Media Law: Evaluation and Summary. Retrieved August 1, 2014, from http://www.riskandforecast.com/post/hungary/the-new-hungarianmedia-law-evaluation-and-summary 645.html

Political Capital. (2013). New Electoral System in the Home Stretch, An analysis of the effects of the new Hungarian electoral procedure law and the campaign finance law. Retrieved August 2, 2014, from http://www.valasztasirendszer.hu/wpcontent/uploads/PC New Electoral System In The Home Stretch 20130723.pdf

Przeworski, A. (1991). Democracy and the market: political and economic reforms in Eastern Europe and Latin America. Cambridge: Cambridge University Press.

Przeworski, A., Alvarez, M., Cheibub, J. A., \& Limongi, F. (1996). What Makes Democracies Endure? Journal of Democracy, 7(1), 39-55.

Renwick, A. (2010). The politics of electoral reform : changing the rules of democracy. Cambridge/New York: Cambridge University Press.

Roberts, A. L. (2010). The quality of democracy in Eastern Europe: public preferences and policy reforms. Cambridge: Cambridge University Press.

Rokkan, S., \& Lipset, S. M. (1967). Party systems and voter alignments: cross-national perspectives. New York: Free Press.

Rose, R., \& Makkai, T. (1995). Consensus or dissensus about welfare in post-communist societies? European Journal of Political Research, 28(2), 203-224.

Rose, R., \& Mishler, W. (1998). Negative and Positive Party Identification in Post-Communist Countries. Electoral Studies, 17(2), 217-234.

Rosenblum, N. L. (2008). On the side of the angels: an appreciation of parties and partisanship. Princeton N.J.: Princeton University Press.

Rothschild, J., \& Wingfield, N. M. (2000). Return to diversity : a political history of East Central Europe since World War II (3rd ed. ed.). New York: New York : Oxford University Press.

Rupnik, J. (2007). From democracy fatigue to populist backlash. Journal of Democracy, 18(4), 17-25.

Saltman, E. M. (2014). Turning Right: Contemporary Political Socialization of the Hungarian Youth. (PhD), University College London.

Sartori, G. (1968). The sociology of parties: a critical review. In O. Stammer (Ed.), Party systems, party organizations, and the politics of new masses. Berlin: Freie Universität, Institut für Politische Wissenschaft.

Saward, M. (2010). The representative claim. Oxford: Oxford University Press.

Schatz, E. (Ed.). (2009). Political ethnography: what immersion contributes to the study of power. Chicago: University of Chicago Press.

Schedler, A. (1998). What is Democratic Consolidation? Journal of Democracy, 9(2), 91-107.

Schensul, J. J., \& LeCompte, M. D. (Eds.). (1999). The ethnographer's toolkit. Walnut Creek Calif.: AltaMira Press.

Schmidt, V. A. (2008). Discursive Institutionalism: The Explanatory Power of Ideas and Discourse. Annual review of Political Science, 11(1), 303-326.

Schmitter, P. C. (1992). The consolidation of democracy and representation of social groups. American Behavioural Scientist, 35(March/June), 422-449.

Schmitter, P. C., \& Karl, T. L. (1991). What Democracy Is . . and Is Not. Journal of Democracy, 2(3), 75-88.

Schneider, C. Q., \& Schmitter, P. C. (2004). Liberalization, transition and consolidation: measuring the components of democratization. Democratization, 11(5), 59-90.

Schumpeter, J. A. (1943). Capitalism, socialism, and democracy. London: G. Allen \& Unwin ltd. 
Sikk, A. (2005). How unstable? Volatility and the genuinely new parties in Eastern Europe. European Journal of Political Research, 44, 391-412.

Sitter, N., \& Batory, A. (2006). Election Briefing $n^{\circ} 28$, Europe and the Hungarian elections of April 2006. Retrieved September 22, 2014, from https://http://www.sussex.ac.uk/webteam/gateway/file.php?name=epern-election-briefingno-28.pdf\&site $=266$

Sniderman, P. M., \& Theriault, S. M. (2004). The Structure of Political Argument and the Logic of Issue Framing. In W. E. Saris \& P. M. Sniderman (Eds.), Studies in Public Opinion (pp. 133165). Princeton: Princeton University Press.

Stanley, B. (2008). The thin ideology of populism. Journal of Political Ideologies, 13(1), 95-110.

Stark, D., \& Bruszt, L. (1998). Postsocialist pathways : transforming politics and property in East Central Europe. Cambridge/New York: Cambridge University Press.

Steiner, J. r., Bächtiger, A., Spörndli, M., \& Steenbergen, M. R. (2004). Deliberative politics in action : analyzing parliamentary discourse. Cambridge: Cambridge University Press.

Szczerbiak, A. (2001). The 'professionalization' of party campaigning in post-Communist Poland. In P. G. Lewis (Ed.), Party development and democratic change in postCommunist Europe : the first decade (pp. 79-92). London: Frank Cass.

Szczerbiak, A., \& Hanley, S. (2004). Introduction: Understanding the Politics of the Right in Contemporary East-Central Europe. Journal of Communist Studies and Transition Politics, 20(3), 1-8.

Székely, L. (2014). Opinion of the Hungarian Ombudsman Lászlo Székely on the legality of KEHI's state audit on NGO's financed through the Norwegian Civil Support Fund. Retrieved September 8, 2014, from http://www.transparency.hu/uploads/docs/ombudsman levele miniszterelnoksegnek.pdf

Szikinger, I. (2001). Hungary's Pliable Constitution. In J. Zielonka (Ed.), Democratic consolidation in Eastern Europe. Vol. 1, Institutional engineering. Oxford: Oxford University Press.

Tavits, M. (2012). Organizing for Success: Party Organizational Strength and Electoral Performance in Postcommunist Europe. The Journal of Politics, 74(01), 83-97.

Tismaneanu, V. (1998). Fantasies of salvation : post-communist political mythologies. Princeton NJ: Princeton University Press.

Tismaneanu, V. (2002). Discomforts of victory: democracy, liberal values, and nationalism in post-communist Europe. San Domenico di Fiesole Italy: European University Institute, Robert Schuman Centre.

Tóka, G. (1996). Parties and electoral choices in east-central Europe. In P. G. Lewis \& G. Pridham (Eds.), Stabilising fragile democracies : comparing new party systems in southern and eastern Europe (pp. 100-125). London: Routledge.

Tóka, G. (1998). Party Appeals and Voter Loyalty in New Democracies. Political Studies, XLVI, 589610.

Toole, J. (2000). Government Formation and Party System Stabilization in East Central Europe. Party Politics, 6(4), 441-461.

Transparency International Hungary. (2014). Transparency International turns to the Ombudsman regarding recent government audit. Retrieved September 8, 2014, from http://www.transparency.hu/TI turns to the Ombudsman regarding recent government au dit? bind info=index\&bind id $=0$

Troev, T., \& Buckley, N. (2013, May 10, 2013). Bulgarian elections marred by claims of voting fraud. Financial Times [online]. Retrieved from http://www.ft.com/intl/cms/s/0/a99213a8-b98d-11e2-bc57-00144feabdc0.html 
Tworzecki, H. (2003). Learning to choose: Electoral politics in East-Central Europe. Stanford California: Stanford University Press.

United States Commission on Security and Cooperation in Europe. (2013). Helsinki Commission hearing on "The trajectory of Democracy - Why Hungary Matters". Retrieved July 23, 2014, from http://csce.gov/index.cfm?FuseAction=ContentRecords.ViewDetail\&ContentRecord id=539\&Re gion $\mathrm{id}=0$ \&Issue $\mathrm{id}=0$ \&ContentType $=\mathrm{H}, \mathrm{B} \&$ ContentRecordType $=\mathrm{H} \& \mathrm{CFID}=26361986 \& \mathrm{CFTOKEN}=\mathrm{C}$ 913fa608e26bcce-DF0375B6-9908-1777-4C6667FC43655A4F >

Urbinati, N. (2006). Representative democracy: principles and genealogy. Chicago: University of Chicago Press.

Vachudova, M. A. (2008). Tempered by the EU? Political parties and party systems before and after accession. Journal of European Public Policy, 15(6), 861-879.

van Biezen, I. (2003). Political parties in new democracies : party organization in Southern and East-Central Europe. Basingstoke: Palgrave Macmillan.

van der Brug, W., Franklin, M., \& Tóka, G. (2008). One electorate or many? Differences in party preference formation between new and established European democracies. Electoral Studies, 27(4), 589-600.

Vanhuysse, P. (2006). Divide and pacify: strategic social policies and political protests in postcommunist democracies. Budapest: Central European University Press.

White, J. (2009). The Social Theory of Mass Politics. The Journal of Politics, 71(01), 96-112.

White, J. (2011). Political allegiance after European integration. Houndmills Basingstoke Hampshire: Palgrave Macmillan.

White, J., \& Ypi, L. (2010). Rethinking the Modern Prince: Partisanship and the Democratic Ethos. Political Studies, 58(4), 809-828.

White, J., \& Ypi, L. (2011). On Partisan Political Justification. American Political Science Review, 105(02), 381-396.

Wittenberg, J. (2006). Crucibles of political loyalty : church institutions and electoral continuity in Hungary. New York/Cambridge: Cambridge University Press.

Yanow, D., \& Schwartz-Shea, P. (2006). Interpretation and method: Empirical research methods and the interpretive turn. Armonk, N.Y.: M.E. Sharpe.

Young, I. M. (2000). Inclusion and democracy. Oxford: Oxford University Press.

Zakaria, F. (1997). The Rise of Illiberal Democracy. Foreign Affairs, 76(6), 22-43.

Zielonka, J. (Ed.). (2001). Democratic consolidation in Eastern Europe. Vol. 1, Institutional engineering. Oxford: Oxford : Oxford University Press. 